\title{
INTERNALISASI PENDIDIKAN KEWIRAUSAHAAN DALAM PEMBELAJARAN DAN PENILAIAN
}

\author{
Endang Mulyani \\ Universitas Negeri Yogyakarta, Indonesia \\ endamg_mulyani@uny.ac.id
}

\begin{abstract}
Abstrak: Penelitian ini bertujuan: 1) menemukan model penginternalisasian pendidikan kewirausahaan dalam pembelajaran dan penilaian ,2) menumbuhkan sikap dan minat berwirausaha siswa SMK. Dengan model Four-D, penelitian dilakukan di SMK Daerah Istimewa Yogyakarta. Hasil penelitian menunjukkan bahwa: 1) Model internalisasi pendidikan kewirausahaan dalam pembelajaran dan penilaian diwujudkan dalam perangkat pembelajaran yang berupa Rencana Pelaksanaan Pembelajaran (RPP), yang didalamnya terinternalisasi nilai-nilai kewirausahaan. 2) Sikap dan minat berwirausaha siswa sebelum dilakukan intervensi model penginternalisasian pendidikan kewirausahaan dalam kategori cukup, setelah implementasi model penginternalisasian pendidikan kewirausahaan ke dalam pembelajaran dan penilaian mampu meningkatkan sikap dan minat berwirausaha. Hal ini ditunjukkan oleh hasil uji $t$ antara kelompok eksperimen dan kelompok kontrol menunjukkan adanya perbedaan yang signifikan (nilai t: 5,35 untuk sikap dan 2, 549 untuk minat wirausaha).
\end{abstract}

Kata kunci: Pendidikan Kewirausahaan, Sikap, Minat, Pembelajaran, dan Penilaian

\section{THE INTERNALIZATION OF ENTREPRENEURSHIP EDUCATION ON LEARNING AND ASSESSMENT}

\begin{abstract}
This study aims to: 1) find an entrepreneurship education entrepreneurship model in learning and assessment, 2) foster entrepreneurial attitudes and interests of vocational students. With the Four-D model, research was conducted at the Yogyakarta Special Region Vocational School. The results of the study show that: 1) The model of internalization of entrepreneurship education in learning and assessment is realized in the learning tool in the form of Learning Implementation Plans (RPP), in which entrepreneurial values are internalized. 2) Students' entrepreneurial attitudes and interests before being intervened in the entrepreneurship education internalization model in the sufficient category, after the implementation of entrepreneurship education internalization model into learning and assessment can improve entrepreneurial attitudes and interests. This is indicated by the results of the $t$ test between the experimental group and the control group indicating a significant difference ( $t$ value: 5.35 for attitude and 2, 549 for entrepreneurial interest)
\end{abstract}

Keywords: Entrepreneurship Education, Attitude, Interest, Learning, and Assessment

\section{PENDAHULUAN}

Permasalahan yang berkaitan dengan pendidikan kewirausahaan pada saat ini menjadi sorotan isu sentral di masyarakat. Entrepreneurship is an important contributor to new ventures and helps to create jobs, wealth and economic growth. Providing young potential entrepreneurs with the appropriate skills and support is very important, entrepreneurship education being an important element to build a global competitive advantage (Martin, 2012).

Isu tersebut terkait dengan berbagai aspek kehidupan yang tampak dalam berbagai tulisan di media masa, seperti media cetak serta media elektronik. Selain di media masa, para ahli, serta para pengamat pendidikan banyak yang berbicara mengenai permasalahan pendidikan kewirausahaan di forum seminar baik pada tingkat lokal, nasional, dan bahkan internasional. Persoalan yang muncul terkait dengan pendidikan kewirausahaan di masyarakat antara lain adalah rendahnya jumlah wirausaha, rendahnya kreativitas dan kurangnya keberanian menanggung risiko. Berbagai 
alternatif penyelesaian untuk mengatasi permasalahan tersebut telah diajukan, seperti disusunnya peraturan, undang-undang, pelatihan, namun hasilnya belum menunjukkan adanya perubahan yang signifikan.

Sejalan dengan hal tersebut, pelaksanaan pendidikan kewirausahaan di Malaysia dilakukan dalam berbagai bentuk sebagaimana dikemukakan Othman, Hasyim \& Wahid (2012: 698) extracurricular activities have also been implemented in HEIs, in the form of associations, clubs, and so forth. Some universities have also established centres of excellence in entrepreneurship and business, which are operated primarily by students. These activities clearly demonstrate the development of entrepreneurship education in $H E I s$, in line with the government's aspiration to create a distinctive commercial and industrial community in Malaysia".

Kurikulum adalah jantungnya pendidikan (curriculum is the heart of education). Oleh karena itu sudah seharusnya kurikulum sekarang mampu memberikan perhatian yang lebih besar terhadap pendidikan kewirausahaan dibandingkan masa sebelumnya. UU No 20 Tahun 2003 Tentang Sistem Pendidikan Nasional pada Pasal 3, menyatakan bahwa pendidikan nasional berfungsi mengembangkan kemampuan dan membentuk karakter serta peradaban bangsa yang bermartabat dalam rangka mencerdaskan kehidupan bangsa. Dalam UU tersebut dinyatakan juga bahwa pendidikan nasional bertujuan untuk mengembangkan potensi peserta didik agar menjadi manusia yang beriman dan bertakwa kepada Tuhan Yang Maha Esa, berakhlak mulia, sehat, berilmu, cakap, kreatif, mandiri, dan menjadi warga negara yang demokratis serta bertanggung jawab.

Berdasarkan fungsi dan tujuan pendidikan nasional, menunjukkan bahwa pendidikan di setiap jenjang, termasuk Sekolah Menengah Kejuruan (SMK) harus diselenggarakan secara sistematis guna mencapai tujuan tersebut. Permasalahannya adalah apakah pendidikan di SMK telah diselenggarakan dengan baik dan mencapai hasil seperti yang diharapkan. Untuk melihat mutu penyelenggaraan pendidikan dapat dilihat dari beberapa indikator. Beberapa indikator mutu hasil pendidikan yang selama ini digunakan diantaranya adalah nilai Ujian Nasional (UN), persentase kelulusan, angka Drop Out (DO), angka mengulang kelas, persentase lulusan yang melanjutkan jenjang pendidikan di atasnya. Indikator-indikator tersebut cenderung bernuansa kuantitatif, mudah pengukurannya, dan bersifat universal. Di samping indikator kuantitatif, indikator mutu hasil pendidikan lainnya yang sangat penting untuk dicapai adalah indikator kualitatif yang meliputi: beriman dan bertakwa kepada Tuhan Yang Maha Esa, berakhlak mulia, sehat, berilmu, cakap, kreatif, mandiri, dan menjadi warga negara yang demokratis serta bertanggung jawab. Indikator kualitatif berkaitan dengan pembentukan karakter kewirausahaan peserta didik yang terkait dengan pembentukan sikap dan minat berwirausaha siswa sehingga mampu bersaing, dan memiliki sikap serta minat berwirausaha.

Berkaitan dengan ketercapaian tujuan pendidikan nasional terutama yang mengarah pada pembentukan sikap dan minat berwirausaha siswa, selama ini belum dapat diketahui secara pasti. $\mathrm{Hal}$ ini mengingat pengukurannya cenderung bersifat kualitatif, dan belum ada standar nasional untuk menilainya. Terlepas dari berbagai kekurangan dalam praktik pendidikan di Indonesia, apabila dilihat dari Standar Nasional Pendidikan yang menjadi acuan pengembangan kurikulum, pembinaan terkait dengan nilai-nilai kewirausahaan juga harus direalisasikan oleh siswa dalam kehidupan sehari-hari. Permasalahannya, pendidikan kewirausahaan di sekolah selama ini baru mampu menyentuh pada tingkatan pengenalan nilai-nilai seperti pendidikan kewirausahaan hanya sebatas mempelajari buku-buku tanpa melakukan praktek. Namun pada tingkatan internalisasi dan tindakan nyata dalam kehidupan sehari-hari masih perlu ditingkatkan.

Untuk mengatasi permasalahan tersebut, tampaknya perlu dikembangkan model penginternalisasian pendidikan kewirausahaan dalam pembelajaran dan penilaian pada setiap mata 
pelajaran. Dengan demikian, pengembangan nilai-nilai kewirausahaan tidak hanya pada tataran pengenalan, tetapi mampu menyentuh pada internalisasi, dan pengamalan nyata dalam kehidupan peserta didik sehari-hari di masyarakat. Penanaman nilai-nilai kewirausahaan dapat diinternalisasi secara luas melalui proses pembelajaran. Sebagai contoh Finlandia yang telah mempromosikan pendidikan kewirausahaan. "Finland in particular has extensively promoted entrepreneurship education in curricula reforms undertaken at all education levels. For example, entrepreneurship education has been one of the so-called cross-curricular themes for basic education since 1994 and for upper secondary education since 2003 (Seikkula-Leino, at all, 2010)"

Tidak hanya di Indonesia yang gencar melakukan pengembangan kewirausahaan melalui dunia pendidikan. Malaysia juga melakukan pengembangan sumber daya manusia melalui pendidikan dan kewirausahaan sebagaimana Othman, Hasyim \& Wahid (2012: 697-698): "One of the strategies adopted by the Malaysian Government to develop excellent, resilient, and competitive human capital is education and entrepreneurship training. The Higher Education Entrepreneurship Development Policy was launched in February 2010, with the primary goal of generating high-quality human capital, with entrepreneurial thinking, attributes, and values, and the secondary goal of producing more graduate entrepreneurs to act as catalysts for economic transformation."

\section{METODE}

Penelitian ini merupakan penelitian deskriptif yang dilakukan dengan pendekatan Research and Development. Model pengembangan dalam penelitian ini menggunakan four-d model (Thiaragajan et.al, 1994). Penelitian ini dilaksanakan di Sekolah Menengah Kejuruan (SMK) Daerah Istimewa Yogyakarta. Teknik pengumpulan data yang digunakan dalam penelitian ini adalah dokumentasi, angket, observasi dan tes. Beberapa tahapan yang akan dilaksanakan dalam penelitian ini meliputi: a) Tahap persiapan, peneliti melaksanakan kegiatan berupa mengembangkan draf model penginternalisasian pendidikan kewirausahaan dalam pembelajaran dan penilaian yang meliputi seperangkat instrumen serta rubrik evaluasi pelaksanaan pembelajaran dan penilaian yang terinternalisasi dengan pendidikan kewirausahaan. b) Tahap riviu pakar, setelah draf model selesai dikembangkan, kemudian dimintakan masukan kepada pakar dan dilakukan revisi model. c) Tahap ujicoba model di kelas. d) Tahap pengumpulan data penelitian. e) Tahap pengolahan data, beberapa kegiatan yang dilaksanakan dalam tahap ini adalah melaksanakan tabulasi data, reduksi data, pengelompokan data, dan analisis data. F) Tahap pengkajian dan penafsiran. g) Tahap penulisan laporan, pada tahap ini dilakukan kegiatan penulisan laporan akhir penelitian.

Teknik analisis data yang digunakan dalam penelitian ini adalah: a) Untuk melihat hasil uji coba model penginternalisasian pendidikan kewirausahaan digunakan teknis analisis diskriptif. b) Untuk mengetahui perbedaan sikap, minat, dan perilaku wirausaha pada siswa SMK sebelum dan setelah intervensi digunakan teknik analisis statistik diskriptif dan uji t.

\section{HASIL DAN PEMBAHASAN}

\section{Hasil Pengembangan Model}

Pendidikan kewirausahaan bertujuan untuk membentuk manusia secara utuh (holistik), yaitu mengembangkan aspek emosi, sosial, kreativitas dan intelektual peserta didik secara optimal. Pada dasarnya, pendidikan kewirausahaan dapat diimplementasikan secara terpadu dengan kegiatankegiatan pendidikan di sekolah, antara lain dapat diintegrasikan ke dalam pembelajaran.

Pembelajaran yang digunakan dalam penelitian ini adalah menggunakan pembelajaran berbasis proyek pendidikan kewirausahaan. Proyek dalam pembelajaran ini dirancang pada kompetensi dasar produksi, distribusi dan konsumsi. Langkah-langkah dalam pembelajaran proyek ini adalah: 
a) kegiatan produksi di kelas dan simulasi jual beli, b) Presentasi business plan untuk produksi barang oleh siswa, dan c) Presentasi penjualan untuk produksi barang oleh siswa.

Produk yang dihasilkan dalam penelitian ini berupa suatu model penginternalisasian pendidikan kewirausahaan dalam pembelajaran dan penilaian di Sekolah Menengah Kejuruan (SMK). Model penginternalisasian pendidikan kewirausahaan ke dalam pembelajaran dan penilaian diwujudkan dalam bentuk perangkat pembelajaran yang berupa Rencana Pelaksanaan Pembelajaran (RPP) yang di dalamnya terintegrasi nilai-nilai kewirausahaan. Model penginternalisasian/pengintegrasian pendidikan kewirausahaan menggambarkan cara bagaimana seorang guru dapat mengintegrasikan pendidikan kewirausahaan dalam pembelajaran dan penilaian. Cara tersebut terdiri dari beberapa langkah sebagai berikut:

1. Guru memilih materi yang dapat diintegrasikan dengan pendidikan kewirausahaan.

2. Guru menyiapkan perangkat pembelajaran dan penilaian secara lengkap mengacu pada Kurikulum yang diberlakukan di sekolah. Perangkat-perangkat dalam bentuk Rencana Pelaksanaan Pembelajaran (RPP) dan rancangan penilaian.

3. Guru melakukan pre-test untuk mendapatkan tingkat awal dari sikap dan minat berwirausaha siswa.

4. Guru melaksanakan proses pembelajaran dan penilaian hasil belajar yang terintegrasi dengan pendidikan kewirausahaan mengacu pada perencanaan yang telah dipersiapkan.

5. Guru melakukan proses pembelajaran dengan membagikan lembar kerja siswa (LKS) kepada siswa. LKS dikerjakan secara berkelompok dalam proses pembelajaran.

6. Guru memberikan motivasi kepada siswa agar dapat lebih bersemangat dalam proses pembelajaran.

7. Dalam proses pembelajaran guru melakukan pengamatan terhadap sikap dan minat berwirausaha siswa.

8. Dalam proses pembelajaran guru menyiapkan instrumen keterlaksanaan dan model pembelajaran yang terintegrasi pendidikan kewirausahaan. Penilaian ini dilakukan untuk melihat apakah pembelajaran sudah dilakukan sesuai dengan RPP yang telah disusun.

9. Guru melaksanakan post-test.

10. Berdasarkan hasil penilaian terhadap proses pembelajaran, model pembelajaran dan hasil pembelajaran, selanjutnya diadakan evaluasi dan revisi terhadap pelaksanaan pembelajaran yang sudah dilaksanakan oleh guru agar supaya keterlaksanaan model pembelajaran untuk waktu berikutnya menjadi lebih baik.

\section{Hasil Analisis Data Sikap dan Minat Berwirausaha Siswa Sebelum Dilakukan Intervensi Model Penginternalisasian Pendidikan Kewirausahaan}

Berdasarkan hasil analisis data dari tiga sekolah yang digunakan untuk uji coba, dapat dilihat bahwa skor rata-rata pre-test sikap dan minat berwirausaha kelompok eksperimen dan kelompok kontrol dapat dilihat dalam tabel 1 .

Tabel 1. Rata-rata Skor pre-test Sikap dan Minat Berwirausaha

\begin{tabular}{cccc}
\hline \multirow{2}{*}{ Variabel } & \multicolumn{3}{c}{ Rata-rata pre-test } \\
\cline { 2 - 4 } & $\begin{array}{c}\text { Kelompok } \\
\text { Eksperimen }\end{array}$ & $\begin{array}{c}\text { Kelompok } \\
\text { Kontrol }\end{array}$ & Perbedaan Nilai* \\
\hline Sikap & 3,37 & 3,36 & 0,01 \\
\hline Minat & 3,09 & 3,14 & $-0,05$ \\
\hline
\end{tabular}

Keterangan ${ }^{*}$ ) $=$ nilai rata-rata pre-test kelompok eksperimen-nilai rata-rata kelompok kontrol 
Berdasarkan tabel 1, dapat dilihat bahwa nilai rata-rata pre-test untuk sikap dan minat berwirausaha pada kelompok eksperimen dan kelompok kontrol tidak ada perbedaan yang berarti (perbedaaanya relatif kecil), meskipun nilai rata-rata pada siswa kelompok kontrol sedikit lebih besar.

Tabel 2. Rata-Rata Skor pre-test dan post-test Sikap dan Minat Berwirausaha

\begin{tabular}{lllllll}
\hline \multirow{2}{*}{ Variabel } & \multicolumn{2}{l}{ Nilai Rata-rata pre-test } & \multicolumn{3}{l}{ Nilai Rata-rata post-test } \\
\cline { 2 - 7 } & Eksperimen & Kontrol & $\begin{array}{l}\text { Perbedaan } \\
\text { Nilai* }\end{array}$ & Eksperimen & Kontrol & $\begin{array}{l}\text { Perbedaan } \\
\text { Nilai* }\end{array}$ \\
\hline Sikap & 3,37 & 3,36 & 0,01 & 3,46 & 3,18 & 0,28 \\
\hline Minat & 3,09 & 3,14 & $-0,05$ & 3,16 & 3,04 & 0,12 \\
\hline
\end{tabular}

Keterangan*) = rata-rata skor kelompok eksperimen dan kontrol

\section{Peningkatan Skor Sikap dan Minat Berwirausaha Siswa Setelah Diberi Intervensi Model} Pembelajaran dan Penilaian yang Terinternalisasi Pendidikan Kewirausahaan

Peningkatan skor sikap dan minat berwirausaha pada kelompok kontrol dan kelompok eksperimen dapat dilihat dari skor rata-rata pre-test dan post-test. Skor rata-rata pre-test dan post-test sikap dan minat berwirausaha kelompok eksperimen dan kelompok kontrol dapat dilihat pada tabel 2.

Tabel 3. Jumlah Siswa Kelompok Kontrol Menurut Kategori Skor Pre-test dan Postest Sikap Terhadap Wirausaha

\begin{tabular}{ccccc}
\hline \multirow{2}{*}{ Kategori } & \multicolumn{2}{c}{ Skor Pre-test } & \multicolumn{2}{c}{ Skor Postest } \\
\cline { 2 - 5 } & Frekuensi & $\%$ & Frekuensi & $\%$ \\
\hline Rendah & 1 & 1 & 0 & 0 \\
Cukup & 53 & 61 & 47 & 54 \\
Tinggi & 33 & 38 & 40 & 46 \\
\hline Jumlah & 87 & 100 & 87 & 100 \\
\hline
\end{tabular}

Seperti yang telah dipaparkan pada tabel 1 dan 2, dapat dilihat bahwa skor rata-rata pre-test variabel sikap dan minat berwirausaha pada kelompok eksperimen dan kelompok kontrol perbedaannya tidak begitu besar, namun skor rata-rata pre-test lebih besar pada kelompok kontrol. Setelah diberi intervensi model pengintegrasian pendidikan kewirausahaan dalam pembelajaran dan penilaian, skor rata-rata post-test yang diperoleh cenderung lebih besar pada kelompok eksperimen atau kelas yang mendapatkan intervensi/tindakan dengan perbedaan skor rata-rata yang paling besar terletak pada sikap terhadap wirausaha sebesar 0.28 dan disusul minat terhadap wirausaha sebesar 0.12 . Melalui hasil analisis dari pengkategorian sikap dan minat berwirausaha dilihat dari skor pre-test dan post-test pada kelompok eksperimen dan kelompok kontrol dapat dilihat pada tabel 3 .

Tabel 4. Jumlah Siswa Kelompok Eksperimen Menurut Kategori Nilai pre-test dan postest Sikap Terhadap Wirausaha

\begin{tabular}{ccccc}
\hline \multirow{2}{*}{ Kategori } & \multicolumn{2}{c}{ Skor pre-test } & \multicolumn{2}{c}{ Skor pos-test } \\
\cline { 2 - 5 } & Frekuensi & $\%$ & Frekuensi & $\%$ \\
\hline Rendah & 0 & 0 & 0 & 0 \\
Cukup & 54 & 62 & 11 & 13 \\
Tinggi & 33 & 38 & 76 & 87 \\
\hline Jumlah & 87 & 100 & 87 & 100 \\
\hline
\end{tabular}


Berdasarkan data yang diperoleh, jumlah siswa kelompok kontrol menurut kategori nilai pretest dan posttest sikap terhadap wirausaha terjadi kenaikan pada kategori tinggi sebesar $8 \%$.

Berdasarkan hasil analisis data yang diperoleh, jumlah siswa kelompok eksperimen menurut kategori skor pre-test dan postest sikap terhadap wirausaha terjadi kenaikan pada kategori tinggi sebesar $49 \%$. Berdasarkan hasil tersebut dapat disimpulkan bahwa sikap terhadap wirausaha siswa mengalami kenaikan yang cukup besar pada kelompok eksperimen.

Tabel 5. Jumlah Siswa Kelompok Kontrol Menurut Kategori Skor Pre-test \& Postest Minat Siswa Terhadap Wirausaha

\begin{tabular}{ccccc}
\hline \multirow{2}{*}{ Kategori } & \multicolumn{2}{c}{ Skor Pre-test } & \multicolumn{2}{c}{ Skor Postest } \\
\cline { 2 - 5 } & Frekuensi & $\%$ & Frekuensi & $\%$ \\
\hline Rendah & 0 & 0 & 0 & 0 \\
Cukup & 74 & 85 & 72 & 83 \\
Tinggi & 13 & 15 & 15 & 17 \\
\hline Jumlah & 87 & 100 & 87 & 100 \\
\hline
\end{tabular}

Berdasarkan tabel 5. dapat dilihat bahwa jumlah siswa kelompok kontrol menurut kategori skor pre-test dan postest minat terhadap wirausaha terjadi kenaikan pada kategori tinggi sebesar $2 \%$.

Tabel 6. Jumlah Siswa Kelompok Eksperimen Menurut Kategori Skor Pre-test dan Postest Minat Siswa Terhadap Wirausaha

\begin{tabular}{ccccc}
\hline \multirow{2}{*}{ Kategori } & \multicolumn{2}{c}{ Skor Pre-test } & \multicolumn{2}{c}{ Skor Postest } \\
\cline { 2 - 5 } & Frekuensi & $\%$ & Frekuensi & $\%$ \\
\hline Rendah & 1 & 1 & 0 & 0 \\
Cukup & 77 & 89 & 57 & 66 \\
Tinggi & 9 & 10 & 30 & 34 \\
\hline Jumlah & 87 & 100 & 87 & 100 \\
\hline
\end{tabular}

Berdasarkan data yang diperoleh, jumlah siswa kelompok eksperiman menurut kategori skor pre-test dan postest minat terhadap wirausaha terjadi kenaikan pada kategori tinggi sebesar $24 \%$. Berdasarkan hasil analisis tersebut dapat disimpulkan bahwa minat terhadap wirasuaha siswa cenderung lebih besar pada kelompok eksperimen.

Tabel 7. Hasil Uji t (t-test)

\begin{tabular}{cccccc}
\hline Variabel & & Kelompok & Rerata & T & sig. \\
\hline Sikap Kewirausahaan & (Pre Test) & Eksperimen & 3.189 & .145 & .884 \\
\cline { 3 - 5 } & & Kontrol & 3.181 & & \\
\cline { 3 - 5 } Minat Berwirausaha & \multirow{2}{*}{ (Pre Test) $)$} & Eksperimen & 2.956 & -1.087 & .279 \\
\cline { 3 - 5 } & & Kontrol & 3.007 & & \\
\cline { 3 - 5 } & & Kontrol & 2.818 & & \\
\hline Sikap Kewirausahaan & (Post Test) & Eksperimen & 3.466 & 5.350 & .000 \\
\cline { 3 - 5 } & & Kontrol & 3.189 & & \\
\hline Minat Berwirausaha & (Post Test) & Eksperimen & 3.165 & 2.549 & .012 \\
\cline { 3 - 5 } & & Kontrol & 3.044 & & \\
\cline { 3 - 5 } & & Kontrol & 2.962 & & \\
\cline { 3 - 5 } & & &
\end{tabular}


Berdasarkan hasil t-test pada tabel 7, secara keseluruhan pada variabel sikap terhadap wirausaha dan minat terhadap wirausaha dapat disimpulkan bahwa sebelum dan sesudah implementasi pengintegrasian pendidikan kewirausahaan ada perbedaan secara signifikan pada kategori minat terhadap wirausaha, sedang pada kategori sikap terhadap wirausaha ada perbedaan signifikan setelah diterapkan implementasi.

Berdasarkan tabel 7. dapat dilihat bahwa variabel sikap dan minat terhadap wirausaha siswa mengalami peningkatan. Dari tabel 7 tersebut juga dapat dilihat bahwa variabel sikap dan minat berwirausaha mengalami peningkatan, dilihat dari signifikannya, variabel sikap dan minat berwirausaha mengalami perubahan positif signifikan, (lihat hasil uji $t$ ).

\section{SIMPULAN}

Pendidikan kewirausahaan bertujuan untuk membentuk manusia secara utuh (holistic), yaitu mengembangkan aspek emosi, sosial, kreativitas dan intelektual peserta didik secara optimal. Pada dasarnya, pendidikan kewirausahaan dapat diimplementasikan secara terpadu dengan kegiatankegiatan pendidikan di sekolah, antara lain dapat diintegrasikan ke dalam pembelajaran.

Pembelajaran yang digunakan dalam penelitian ini adalah menggunakan pembelajaran berbasis proyek pendidikan kewirausahaan. Proyek dalam pembelajaran ini dirancang pada kompetensi dasar produksi, distribusi dan konsumsi. Langkah-langkah dalam pembelajaran proyek ini adalah: a) kegiatan produksi di kelas dan simulasi jual beli, b) Presentasi business plan untuk produksi barang oleh siswa, dan c) presentasi penjualan untuk produksi barang oleh siswa.

Untuk melihat peningkatan sikap dan minat berwirausaha siswa dilihat melalui skor ratarata pre-test kelompok kontrol dan kelompok eksperimen. Model pengintegrasian pendidikan kewirausahaan ke dalam pembelajaran di SMK ditunjukkan oleh perangkat pengintegrasian pendidikan kewirausahaan dalam pembelajaran di SMK dalam hal ini adalah berupa RPP yang di dalamnya terintegrasi nilai-nilai kewirausahaan. Sikap dan minat berwirausaha siswa SMK sebelum implementasi model pengintegrasian menunjukkan kondisi yang relatif sama antara kelompok eksperimen dan kelompok kontrol yakni rata-rata dalam kategori kelompok cukup. Peningkatan sikap dan minat berwirausaha siswa SMK setelah ada intervensi model pengintegrasian pendidikan kewirausahaan dalam pembelajaran bisa terjadi peningkatan secara signifikan.

\section{DAFTAR PUSTAKA}

Martin, C. 2012. Promoting the Entrepreneurship Education Using a Blended Learning Approach. The $8^{\text {th }}$ Internation Scientific Conference eLearning and Software for Education. Bucharest, April 26272012.

Othman, N., Hashim, N,. \& Wahid, H. A. 2012. Readiness Toward Entrepreneurship Education Students and Malaysian Universities. Education and Training Journal. Vol 54. No. 8/9. Diakses dari https://search.proquest.com/docview/1154221246/76887D4464841DDPQ/1?accountid=31324 pada hari Selasa tanggal 28 November 2017 pukul 12.59 WIB.

Seikkula Leino, at all. 2010. Promoting Entrepreneurship Education: the role of the teacher. Diakses dari http://search.proquest.com/docview/237079084/fulltextPDF/EE526817AB1441F4PQ/8?accountid= $\underline{31324}$ pada hari Senin tanggal 10 April 2017 pukul 11.26 WIB

Thiaragajan. 1994. Lecture Games : From Passive Presentations to Interactive Instruction. HRD PressUU No 20 Tahun 2003 Tentang Sistem Pendidikan Nasional pada Pasal 13 Ayat 1. 